Light," in which the suitability of the electric glow lamp for domestic lighting was dealt with.

Swan played a considerable part in connection with the introduction of the improvements in the manufacturing processes which have resulted in the successive reductions in the price of the glow lamp. To him was due the introduction of the "parchmentised thread" filaments formed by treating ordinary crochet cotton-thread with sulphuric acid and then carbonising the same; later he devised the process whereby filaments of exceedingly small diameter and great uniformity were obtained by squirting artificial cellulose by hydraulic pressure through a die; the latter being first shown to the public at the Inventions Exhibition in 1885 . It is only very recently that this process of manufacture has given place to the newly developed metal filament lamps.

Swan's activities in the field of electro-chemistry resulted in the invention by him of a rapid process of depositing copper, due to the discovery made by him that the addition of a suitable quantity of gelatine to the solution in the electro-depositing bath much improved the quality of the deposited metal. The process admits of the utilisation of currents of from 1000 to 1500 amperes per square foot of kathode, pure copper wire being at once reeled off from the bath through a die. Swan devoted his attention also to apparatus for measuring electric current, and the improvement of secondary batteries; his activities in the field of invention resulted in the filing of some sixty patent specifications, some in his name alone and others in the joint names of himself and his eldest son.

A recognition of Swan's services to applied science came first from France when, in 1881, he was appointed Chevalier of the Legion of Honour. In 1894 he was elected a Fellow of the Royal Society, and ten years later received a knighthood. The University of Durham also conferred upon him the honorary degrees of M.A. and D.Sc. He was the recipient, in 1903, of a gold medal from the Society of Chemical Industry, and, in 1904, of the Hughes medal from the Royal Society. In 1906 the Royal Society of Arts awarded him its Albert medal, "for the part he took in the invention of the incandescent lamp and for his invention of the carbon process of photographic printing," the medal being presented to him by King George (at that time Prince of Wales).

The career of Swan demonstrates that a scientific training and the possession of inventive faculties are not, as some suppose, necessarily incompatible with the possession of sound business capacity; and, indeed, the subject of this memoir gave ample evidence by his life work that it is possible for a man to be a productive inventor and at the same time successful as a commercial manager.

In Sir Joseph Swan the nation has lost not only a venerable investigator, whose labours did much for the material progress of civilisation, but one who was also possessed of a charming personality which deservedly endeared him to a large circle of friends and acquaintances.

W. A. J. O'M.

\section{DR. P. H. PYE-SMITH, F.R.S.}

PHILIP. HENRY PYE-SMITH was born August 30, 1839, at Billiter Square, E.C. $\mathrm{He}$ was the eldest son of Ebenezer Pye-Smith, F.R.C.S., and the grandson of the Rev. Dr. John Pye-Smith, F.R.S., the principal of the Homerton Theological College, well known, nearly a century ago, both as a geologist and theologian. He belonged to a medical family, for his father was a surgeon in the city, his brother Rutherford John Pye-Smith is emeritus professor of surgery at the University of Sheffield, and a nephew is also in the profession.

Dr. Pye-Smith was educated at Mill Hill School, and in $185^{8}$ took the B.A. of the University of London. He then entered Guy's Hospital Medical School and attained his M.D. in 1864; he gained the gold medal, thus outstripping two future distinguished colleagues, Moxon and Sir Thomas Stevenson. After a year at continental schools his teaching began by his being appointed demonstrator of anatomy. In $187 \mathrm{I}$ he became assistant physician to Guy's Hospital, and full physician in 1883 . $\mathrm{He}$ retired from the active staff in 1899 , as in that year he reached the retiring age of sixty. He then became consulting physician to the hospital. During the earlier part of his assistant physiciancy he lectured on comparative anatomy, then on physiology, and when he was full physician on medicine. For many years he took charge of the department of diseases of the skin, and was regarded everywhere as one of the highest authorities in this branch of medicine.

In 1870 Pye-Smith was elected a Fellow of the Royal College of Physicians, and he later became examiner, a member of the council, and a censor. From 1900-9 he represented the college on the senate of the University of London, and held the office of vice-chancellor from 1903 to 1905 . He was elected a Fellow of the Royal Society in 1886 , and served on the council of the society in I89I92. In 1899 he was appointed by the British Government joint representative with Sir Heron Maxwell at the International Congress on Tuberculosis in Berlin. He was a member of the General Medical Council and treasurer from I9OI-7. He gave the address in medicine at the meeting of the British Medical Association at Ipswich in Igoo. $\mathrm{He}$ was an hon. M.D. of the University of Dublin, an honorary fellow of the Royal College of Physicians of Philadelphia, and of the Royal Academy of Medicine in Ireland.

In 1883 his colleague Fagge died, leaving by his will the manuscript of his famous book on medicine to Pye-Smith for him to complete and see through the press. Pye-Smith greatly appreciated this act of his friend; he worked hard at the task, and was the means of giving to the world one of the best and most original books on medicine. $\mathrm{He}$ kept it up to date and edited the subsequent editions, so that it gradually contained more and more of Pye-Smith's writing, and the later editions were published as under the joint authorship of Fagge and Pye-Smith. This was his out- 
standing work, but he wrote many medical papers, publishing the chief of them in the Guy's Hospital Reports. He contributed the article on Harvey in the "Encyclopædia Britannica," and delivered the Harveian oration in 1893 . He was an admirable speaker, always saying just the right thing in just the right way. Nothing could have been better than the speech he made at the dinner given to Sir Samuel Wilks by his many admirers when he became a baronet.

Pye-Smith's honesty, his high ideals, his geniality, his affection for all learning--modern or ancient, medical or non-medical-and his many kindnesses especially to younger members of the profession, gave him troops of friends, and no one took more pleasure than he in getting them around him. All who knew him admired and liked him. Unhappily, illness kept him in retirement for several years before his death on May 23. In 1894 he married Gertrude, the youngest daughter of the late Arthur Foulger. She and their only childa son-survive him.

\section{NOTES.}

THE Croonian Lecture of the Royal Society will be delivered on Thursday, June $\mathrm{Ir}$, by Prof. E. B. Wilson, of Columbia University, on the bearing of cytological research on heredity.

THE Institution of Electrical Engineers will hold a conversazione at the Natural History Museum, South Kensington, on Thursday, June 25. A conversazione of the Institution of Civil Engineers will be held at the institution on Thursday, July 2.

Prof. Metchnikoff, of the Pasteur Institute, is to be presented with a "golden" book to celebrate his scientific jubilee and his seventieth birthday. Prof. Metchnikoff, whose scientific work in zoology and microbiology is of a high order, is best known to the general public as the author of "The Prolongation of Life" and "The Nature of Man."

At the Laryngological Section of the Royal Society of Medicine on May 27, Prof. Gustav Killian, of Berlin, demonstrated his method of examining the larynx and its annexes by means of a new instrument, the "suspension" laryngoscope. At the same time, a case of cancer of the throat was shown which had been treated by high-frequency electric currents-so-called diathermy-with promising results.

THE triennial Parkin prize of rool. in the gift of the Royal College of Physicians of Edinburgh, has been awarded to Dr. Johnston-Lavis. The subject set was, "On the Effects of Volcanic Action in the Production of Epidemic Diseases in the Animal and in the Vegetable Creation, and in the Production of Hurricanes and Abnormal Atmospherical Vicissitudes." The prize essay will be published in book form by Messrs. Bale, Sons and Danielsson, Ltd.

Several important earthquakes have occurred during the past week. On May 26 a violent earthquake, the centre of which may have been in Central or South
America, was recorded in European observatories. On May 27 another strong shock was felt at Panama, but again without damaging the canal works. On the same day an earthquake of unusual intensity, which seems to have originated near Tonga, was recorded at Sydney, the disturbance lasting for three hours.

MR. W. B. Grove, writing from the University of Birmingham, says that any person interested in the study of the Uredinales may obtain a supply of the rare and remarkable parasite, Puccinia vincae, in a fresh condition, by sending a stamped and addressed envelope, or other suitable covering, to him at 46 Duchess Road, Birmingham. The specimens show an abundance of the curious debatable bodies called by Plowright "æcidia."

THE seventh congress of the International Association for Testing Materials will be held under the patronage of H.M. the Czar of Russia, in St. Petersburg, on August $12-17,1_{1} 1_{5}$. Four days will be devoted to the discussion of the most important problems on testing materials. After the congress extensive excursions in the interior of Russia have been arranged. The offices of the British section of the Association are at the Iron and Steel Institute, 28 Victoria Street, London, S.W.

THE council of the Royal Society of Edinburgh has awarded the following prizes:-(I) The Neill prize for the biennial period $19 \mathrm{I} 1-\mathrm{I} 2, \mathrm{I}^{\mathrm{I}} \mathrm{I}-\mathrm{I} 3$ to $\mathrm{Dr}$. W. S. Bruce, in recognition of the scientific results of his Arctic and Antarctic explorations; (2) the Keith prize for the biennial period I9II-I2, I9I2-I3 to Mr. J. Russell, for his series of investigations relating to magnetic phenomena in metals and the molecular theory of magnetism, the results of which have been published in the Proceedings and Transactions of the society, the last paper having been issued within the period.

Mr. James W. Munro, Wolfe-Barry student in entomology at the Imperial College of Science and Technology, South Kensington, who is engaged in working out the life-history of Xestobium tesselatum with regard to the roof of Westminster Hall, will be glad to be informed of any timber known to be affected with this beetle, and whether it would be possible for him to obtain it by purchase or to examine it for living beetles. He adds :- "Owing to the precarious condition of Westminster Hall roof, it is desirable that my investigations be carried out as soon as possible and a large supply"of living beetles is the first essential."

Sensational paragraphs on seeing by wire have been going the rounds of the daily Press, but there is no indication in these accounts of anything fundamentally different from the plans that were put forward in the early days of the Physical Society, when the late Mr. Shelford Bidwell, Prof. Ayrton, and others were experimenting with selenium. At that time mosaics of selenium were going to do all that is promised now, but they never did. It may be that Dr. A. M. Low, whose apparatus has been described in perfervid terms in the daily Press, has made some progress, but the published accounts of the invention as "the latest scientific discovery" are absurd. 